\title{
Comparison of student attitudes towards natural sciences
}

\author{
Maison Maison, Haryanto Haryanto, Margaret Dwi Wiwik Ernawati, Yulia Ningsih, \\ Nurdatul Jannah, Tari Okta Puspitasari, Dodi Setiawan Putra \\ Faculty of Education and Teacher Training, Universitas Jambi, Indonesia
}

\begin{tabular}{l} 
Article Info \\
\hline Article history: \\
Received Nov 20, 2019 \\
Revised Jan 2, 2020 \\
Accepted Jan 7, 2020 \\
\hline
\end{tabular}

Keywords:

Attitudes

Junior high school

Natural sciences

\begin{abstract}
The attitude of students during the learning process is essential to be known by an educator to understand how to deal with students in the class. This study aims to determine how students 'attitudes towards science subjects and this study also aim to determine whether there is a comparison of students' attitudes towards natural science subjects in junior high schools in Indonesia. This research was conducted at some state junior high schools in Jambi. Specifically, the research sites were Junior High School 5, Junior High School 6, and Junior High School 26 in Jambi. The research design used in this study was a quantitative approach with survey methods. The research instrument was a science attitude questionnaire. Data were analyzed using descriptive statistics and inferential statistics. The results showed that students' attitudes toward science subjects based on indicators of adoption of scientific attitudes, fun in learning science, and interest in increasing the time to study science were in good categories and also there are significant differences of students' attitude towards science subjects in the three schools with a comparison value of $0.042<0.05$.
\end{abstract}

This is an open access article under the CC BY-SA license.

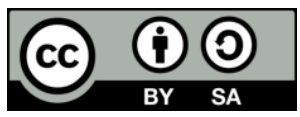

\section{Corresponding Author:}

Maison Maison,

Faculty of Education and Teacher Training,

Universitas Jambi,

Jambi Road - Ma. Bulian, km. 15, Indonesia.

Email: maison@unja.ac.id

\section{INTRODUCTION}

Indonesia is one of the countries which has abundant natural resources in the world. But Indonesia is still categorized as a developing country because of the low human resources. According to [1], in this globalization era, quality human resources will become the foundation of nation incompetency. Thus, it has become a top priority for education to produce generations of intellectuals, one of which is through higher education. Education is one way to increase human resources because, in education, there is some learning process that is carried out consciously to be able to develop the potential of students. As stated by [2, 3], education plays an active role in improving the quality of human resources. According to [4, 5] Education is also used as an effort to develop the learners' potential through the learning activities. Education is the best and effective way to save a country through the development of generations with a good attitude $[6,7]$. Education is also a process of learning that is done consciously to be able to develop the potential of students, not only cognitive abilities but also the ability to control themselves as shown through attitude. So, with education, it can increase the potential and character of human resources.

Character education must be applied in schools, to develop students' character better. According to [8] with character education, students can independently improve and use a variety of knowledge, study, internalize and personalize character values so that they appear in daily behavior. In Indonesia, there are four levels of education, namely education for early childhood, elementary schools, secondary schools, and 
tertiary institutions. Formal education in Indonesia starts with primary education, followed by secondary education and then tertiary education [9]. There are two levels of education at secondary education, i.e., junior high school (SMP) and senior high school (SMA). Students must be passed SMP before going to SMA. SMP is an institution for further study after a student has completed education in elementary school. In the structure of the SMP curriculum, there are various subjects, and one of them is natural science. Learning natural science is very important in shaping student attitudes. R. Darmawangsa, et al [10] state that the attitude in learning is very important, as is the attitude in learning towards school subjects. The attitude of students be in the form of responses to subjects, especially natural science.

Science learning is an activity carried out by teachers and students to learn the forms and events related to the universe. Natural science is a subject that needs a learning process that is highly associated with the environment $[11,12]$. Science learning is directed to find out about nature systematically. So that science learning a process of discovery and formation of scientific attitudes [13]. The adoption of scientific attitude plays a role in the learning process so it needs to be applied to students. According to [14], scientific attitude is an attitude must be developed in science lessons. Because with a good scientific attitude the students' attitude is also more positive. The positive attitude in question can be in the form of actions taken at the time of learning. The opinion above shows that scientific attitude influences the learning outcomes of students in learning science. So, one aspect of assessment is the aspect of attitude. Scientific attitude has three components, namely, beliefs, feelings, and actions [15]. This scientific attitude can be in the form of feelings towards subjects, these feelings in the way of students' enjoyment in learning.

Feelings of pleasure in learning affect students' attitudes towards natural science subjects. The happy or like the attitude of the student will deduce the student's pleasure towards science, while the attitude of unhappy or dislike will conclude students have a dislike for science. As stated by $[16,17]$, attitude is the liking and disliking of an individual towards an object, event situation or value. Fun in learning must be provided to students by the teacher. According to [18], the pleasure in education created by the teacher makes students feel happy about the subjects were given. Something positive can increase student motivation and improve student enthusiasm for learning. Therefore, the teacher must know how the attitude of students in the process of learning. Because by knowing the attitude of the student, teachers can improve the learning process in the classroom following the ability that students have. One of the needs to pay attention to is a scientific attitude [19].

Students who feel happy, like, high curiosity, and are interested in learning science will get good learning outcomes. Students' fun in science lessons in class will encourage students to add learning time related to science $[20,21]$. Interest in increasing science learning time can be shown by students with the likes in learning science. Students who like to study science subjects will have a higher curiosity about the subject than other subjects [22]. Therefore, students consciously increase their learning time to explore knowledge about science. The positive attitude of students towards natural science learning will be integrated with the interest in increasing the time to study science. Students who are interested in increasing the amount of time they study in science will get the best results from the science lesson.

Based on this, if you have a good scientific attitude and have a happy feeling when learning science, then in the next stage students will need lots of free time to support good learning outcomes and results. In other words, students who have a good scientific attitude will not spend their free time playing or doing other useless activities. But in fact, students are still less interested in increasing the time for learning science other than in class because they prefer playing compared to learning. Students also only like science lessons if the teacher presents the material with methods that are fun for students. If the teaching method bores students, then students are not enthusiastic about the learning activity. So, teachers and prospective educators need to know the attitudes of students when studying in class. The purpose of this study was to determine how students 'attitudes towards science. Students' attitudes toward science subjects were reviewed in terms of the indicators of scientific attitude adoption, pleasure in learning science and interest in increasing the time of learning science in Junior High School 5, Junior High School 6 and Junior High School 26 at Jambi.

\section{RESEARCH METHOD}

\subsection{Research design}

The design in this study uses a quantitative approach with survey methods. Quantitative research methods are referred to as research methods based on the philosophy of positivism, which is useful for examining specific populations or samples, collecting data using research instruments, analyzing quantitative/statistical data, to test established hypotheses [23]. A quantitative research method is based on the philosophy studies positivism used to conduct a study of a population or a particular sample, data collection instruments, research and quantitative data analysis/statistics [24]. According to [25], research, the survey is a quantitative research procedure in which the researcher manages a sample survey or across 
a population that is used to describe attitudes. In addition, the survey method is a method used to get data from a particular natural place, but researchers do the treatment in data collection, in which by distributing questionnaires, tests and interviews [26]. The design of this study was applied because it was by the objectives of the study, where the aim was to determine the attitude of junior high school students towards science subjects.

\subsection{Research subjects}

This research was conducted in the odd semester of the 2019/2020 school year. The respondents were 1075 students from 3 schools in Jambi, Indonesia, including Junior High School 5, Junior High School 6, and Junior High School 26. The sampling technique in this study was total sampling.

\subsection{Research instrument}

This research instrument uses a science attitude questionnaire that was adapted from the 2018 Astalini and Kurniawan research with a Cronbach alpha value of 0.929. According to [27], the questionnaire used was closed questionnaire, the number of items and alternative answers to be given by the respondent had been determined, the respondent only had to choose it according to the actual situation. The questionnaire used was a Likert scale with a five-choice model (scale of five). Answer categories (SS) Strongly Agree, (S) Agree, (N) Neutral, (TS) Disagree, (STS) Strongly Disagree. The range for each indicator is shown in Table 1.

Table 1. Range of student attitudes toward science subjects

\begin{tabular}{lll}
\hline \multicolumn{1}{c}{ Indicator } & \multicolumn{1}{c}{ Range } & Category \\
\hline & $21.1-25.0$ & Very good \\
Scientific attitude adoption & $17.1-21.0$ & Good \\
& $13.1-17.0$ & Enough \\
& $9.1-13.0$ & Not good \\
& $5.0-9.0$ & Very bad \\
& $29.5-35.0$ & Very good \\
Fun in learning natural science & $23.9-29.4$ & Good \\
& $18.3-23.8$ & Enough \\
& $12.7-18.2$ & Not good \\
Interest in increasing science learning time & $7.0-12.6$ & Very bad \\
& $25.3-30.0$ & Very good \\
& $20.5-25.2$ & Good \\
& $15.7-20.4$ & Enough \\
& $10.9-15.6$ & Not good \\
& $6.0-10.8$ & Very bad \\
\hline
\end{tabular}

\subsection{Data analysis techniques}

In this study, the data were analyzed with two statistics techniques, namely descriptive statistics, and inferential statistics, with the help of SPSS applications. Descriptive statistics utilize and graphical methods to look for patterns in a data set and to present the information that individuals can use to make decisions [28]. While inferential statistics can allow researchers to generalize findings to other, similar language learners; that is, to make inferences [29]. Descriptive statistics were used to see the description of students' attitudes toward science subjects in each school; then, inferential statistics were used to examine the comparison of student attitudes in each school. Inferential parametric statistics used were a one-way ANOVA test.

\section{RESULTS AND DISCUSSION}

\subsection{Results}

An attitude is a form of a person's feelings or perceptions of an object which is described by the expression of liking or not on the object. Students' attitudes when learning can be viewed from the indicators of scientific attitude adoption, fun in learning natural science and interest in increasing natural science learning time. The novelty of this research is to identify how students' attitudes in natural science subjects and find out the differences in the attitudes of students in Junior High School 5, Junior High School 6 and Junior High School 26 who are in Jambi. This research will also help understand science subjects' learning process, especially in schools studied so that teachers can improve the way they teach in the learning process because attitudes students who are kind or positive will be able to socialize well, especially when the learning process. 
According to [30], the attitude of giving an assessment of something, which results in an attitude of accepting, rejecting, or ignoring. In learning activities students can accept, reject, or ignore these learning activities. Such an attitude will play a role in the process and learning outcomes achieved. The attitude of students in science subjects' indicators of the adoption of scientific attitudes can be seen in Table 2.

Table 2. Descriptive statistics of scientific attitude adoption

\begin{tabular}{ccccccccc}
\hline Range & $\begin{array}{c}\text { Classification } \\
\text { Attitudes }\end{array}$ & F & Mean & Median & $\begin{array}{c}\text { Std. } \\
\text { Deviation }\end{array}$ & Min & Max & $\%$ \\
\hline $21.1-25.0$ & Very good & 217 & & & & & & 20.2 \\
$17.1-21.0$ & Good & 571 & & & & & & 53.1 \\
$13.1-17.0$ & Enough & 247 & 19.09 & 19.00 & 2.81 & 9.0 & 25.0 & 23.0 \\
$9.1-13.0$ & Not good & 37 & & & & & & 3.4 \\
$5.0-9.0$ & Very bad & 3 & & & & & & 0.3 \\
& Total & 1075 & & & & & \\
\hline
\end{tabular}

In Table 2, it is known that students' attitudes toward science subjects based on indicators of scientific attitude adoption are categorized well with a percentage of $53.1 \%$. As for the indicators of pleasure in learning science seen in Table 3.

Table 3. Descriptive statistics of fun in learning natural science

\begin{tabular}{ccccccccc}
\hline Range & $\begin{array}{c}\text { Classification } \\
\text { Attitudes }\end{array}$ & F & Mean & Median & $\begin{array}{c}\text { Std. } \\
\text { Deviation }\end{array}$ & Min & Max & $\%$ \\
\hline $29.5-35.0$ & Very good & 125 & & & & & & 11.6 \\
$23.9-29.4$ & Good & 620 & & & & & & 57.7 \\
$18.3-23.8$ & Enough & 285 & 25.13 & 25.00 & 3.71 & 8.0 & 34.0 & 26.5 \\
$12.7-18.2$ & Not good & 44 & & & & & & 4.1 \\
$7.0-12.6$ & Very bad & 1 & & & & & & 0.1 \\
\multicolumn{2}{c}{ Total } & & 1075 & & & & & 100 \\
\hline
\end{tabular}

In Table 3, it is known that students' attitudes towards science subjects based on the indicator of fun in learning natural science are categorized well with a percentage of $57.7 \%$. As for the indicators of interest in increasing science learning time, it can be seen in Table 4.

Table 4. Descriptive statistics of Interest in increasing science learning time

\begin{tabular}{|c|c|c|c|c|c|c|c|c|}
\hline Range & $\begin{array}{r}\text { assification } \\
\text { Attitudes }\end{array}$ & $\mathrm{F}$ & Mean & Median & $\begin{array}{c}\text { Std. } \\
\text { Deviation }\end{array}$ & Min & Max & $\%$ \\
\hline $25.3-30.0$ & Very good & 169 & & & & & & 15.7 \\
\hline $20.5-25.2$ & Good & 513 & & & & & & 47.7 \\
\hline $15.7-20.4$ & Enough & 346 & 21.74 & 22.00 & 3.56 & 8.0 & 30.0 & 32.2 \\
\hline $10.9-15.6$ & Not good & 45 & & & & & & 4.2 \\
\hline $6.0-10.8$ & Very bad & 2 & & & & & & 0.2 \\
\hline \multicolumn{2}{|c|}{ Total } & 1075 & & & & & & 100 \\
\hline
\end{tabular}

In Table 4, it is known that students' attitudes toward science subjects based on indicators of interest in increasing science learning time are considered good with a percentage of $47.7 \%$. Based on Tables 2 , Table 3 and Table 4 it can be concluded that students have a good attitude towards science subjects. To find out the differences in students' attitudes towards science subjects, the normality of data and homogeneity of variance is important. Data is normally distributed or not. If the significance value $>$ alpha value $=$ sig. $>0.05$ then the data is normally distributed. The results of normality tests using SPSS on the population used. After a normality test, the researcher tested the data with a homogeneity test using SPSS. It was done to see whether the data groups had the same variant or not. If the significance value is $>0.05$, then the data has the same variant. Furthermore, the new one-way ANOVA test was conducted to find out whether students' attitudes towards science subjects in the several schools studied were different or not. Data is said to have differences if the significance value $<0.05$.

Based on Table 5, it is known that the data is normally distributed with a significance value greater than 0.05 , namely 0.2 for Junior high school 26, 0.82 for Junior high school 6 , and 0.91 for Junior high school 5. The data is also said to be homogeneous because it is known in the Table that the homogeneity significance value is $0.671>0.05$. After the data is known to be normal and homogeneous then a comparison 
test is performed which obtains a significance value of $0.042<0.05$. So, it is known that there are significant differences in students' attitudes toward science subjects in Junior High School 26, Junior High School 6, and Junior High School 5.

Table 5. Test for normality, homogeneity and one-way ANOVA

\begin{tabular}{lccc}
\hline & SMPN 26 & SMPN 6 & SMPN 5 \\
\hline $\mathrm{N}$ & 154 & 608 & 314 \\
Normalitas (Asymp. Sig. (2-tailed) & .200 & .082 & .091 \\
Homogenitas (sig.) & & 0.671 & \\
One Way Anova (sig.) & & 0.042 & \\
\hline
\end{tabular}

\subsection{Discussion}

Educational success, be seen from the development of students both from student achievement and changes in behavior or attitudes of students in each learning. According to [31], everyone has a different attitude towards something. This is caused by several factors that exist in each individual, such as differences in talent, interests, experience, knowledge, intensity, feelings, and also the environmental situation. Attitude is a behavior that already exists in a person. The attitude becomes very important in education. Where a good attitude can provide a good influence on the level of education. According to [32], the attitude of curiosity, perseverance, openness, honesty, caring, creative, honest, accepting the truth of an existing fact and so on is the meaning of scientific attitude, which attitude is not only useful in school but also useful in social life, and shape the good personality of a person. Scientific attitude, the establishment of a tendency towards a particular stimulus that is always oriented scientific methods [33, 34]. The low scientific attitude, seen from the lack of involvement and independence of students in the process of learning activities. Students tend to be passive, do not dare to express opinions, ashamed to ask questions. So, the lack of interaction between educators and students and students with students [35]. This scientific attitude is used to measure a student's attitude scientifically. According to [36], the adoption of a scientific attitude can measure students 'willingness and readiness to provide scientific responses and students' openness to new information. Students who have high scientific attitudes will help the learning process improve. This is because scientific attitudes can shape students thinking creatively and critically [37, 38]. The attitude of the success of a student determines the material absorbed in the learning process. The success of students to absorb well the teaching materials delivered in the learning process by the teacher will lead to positive learning outcomes in the individual student's natural science [39].

Research reports indicate that the negative attitudes of students were caused by teachers' conventional (lecture) method of teaching $[40,41]$. But, in reality, the learning of science is essential to be learned by students. Science, one of the subjects developed through the inductive approach, has contributed a lot to the development of technology [42]. The cause of students' negative attitudes is due to traditional methods of teaching science that is used continuously, for example, learning takes place passively and students are reluctant to think [43]. Therefore, from that explanation, one of the goals of learning science is to foster positive student attitudes towards science.

Therefore, one of the goals of learning science to foster positive student attitudes. Students rate their 'pleasure' from activities (Hate, Dislike, don't care, Like, love), while the teacher assesses the 'usefulness' of each activity [44]. So, that it is said that the pleasure of students when the process of learning science seen from students responding to learning, in general, the indicators of pleasure in learning science are expressed with pleasure or no. Students who love science lessons will certainly be interested in learning science, and it needs to increase students' interest in learning science. To revive students' interest in science and to overcome negative perceptions of science, the teacher's role is needed [45]. The happy attitude will deduce the student's pleasure towards science. While the attitude of dislike will conclude students have a dislike for science. As stated by [46, 47], if students like, feel happy or have good feelings in a situation or lesson, the student can be said to have a positive attitude, but vice versa, if students have bad feelings or are happy in a situation, means having a negative attitude. So, it can be said that students who are happy about science lessons will be interested in increasing their study time.

One of the students 'attitudes that will trigger students' understanding and insight related to science concepts is the duration of student learning time in the science learning process. Learning time refers to the specific time students set for themselves to learn to gain knowledge [48]. Science learning that is abstract and difficult to understand by students requires more learning time that aims to deepen students' understanding of the concepts of science subjects. Students who have a positive attitude toward science will have an interest in increasing the time to study science because of high curiosity in increasing insight about science. The fun of students in taking science lessons in class will encourage students to add learning time 
related to science [49]. One of the efforts made by students in increasing learning time is by working on problems related to science independently. Not only questions obtained from learning in class but also working on other problems related to science. But not all students want to practice finding and working on science problems independently. To encourage students' interests and positive attitudes in practicing working on science questions, it takes interest and joy from within students. So that the activity of increasing the learning time is very closely related to the joy that is owned by students. When students feel happy and challenged to have a high curiosity about science subjects, students will have an interest in increasing the time of science learning.

Besides the factors that exist in students' other factors that trigger students to be able to increase learning time are how the teacher can motivate and cause a sense of fun in students. According to [50, 51], as a teacher, competence is a skill that must be processed as a provision in teaching. However, it is not easy for the teacher to give a sense of fun to students towards natural science subjects because natural science subjects contain formulas and are difficult to understand. For this reason, teachers need to provide comfort and renewal in teaching to attract students' interest in science learning. The teacher is also the subject involved in the education and learning process. The teacher is not only focused on learning but also must understand the attitudes of his students [52]. Because the success of the learning process is influenced by the quality and way of teaching [53-55]. So, the role of teachers is essential in the success of their students. Teachers should know how to design and practice suitable and effective pedagogical strategies [56]

\section{CONCLUSION}

Attitude is a feeling that someone shows towards a certain object. In science learning, students' attitudes are shown with pleasure or not the student towards science lessons. Based on indicators of the adoption of scientific attitudes, natural science learning pleasure and interest in increasing science learning time, students' attitudes of Junior High School 26, Junior High School 6 and Junior High School 5 were identified as good. Besides, there are differences in the attitudes of students in science subjects with significance after being tested with SPSS. Knowing how students respond in natural science subjects can be used as a guide for teachers to teach further.

\section{REFERENCES}

[1] Darmaji, D. A. Kurniawan, and Irdianti, "Physics education students' science process skills," International Journal of Evaluation and Research in Education (IJERE), vol. 8, no. 2, pp. 293-298, 2019.

[2] Darmaji, D. A. Kurniawan, H. Parasdila, and Irdianti, "Description of science process skills' physics education students at Jambi University in temperature and heat materials," The Ed ucational Review, vol. 2, no. 9, pp. 485-498, USA, 2018.

[3] Asrial, Syahrial, D. A. Kurniawan, and R. Septiasari, "Relationship of pedagogical competence and science competency of elementary school teacher education (in bahasa)," Pedagogia: Jurnal Pendidikan, vol. 8, no. 2, pp. 149-156, 2019.

[4] N. Khoiri, N. Hindarto, and S. Sulhadi, "Development of life skill-based physics learning tools to increase student entrepreneurial interest (in bahasa)," Jurnal Pendidikan Fisika Indonesia, vol. 7, pp. 84-88, 2011.

[5] D. R. Permatasari, H. Soegiyanto, and B. Usodo, "The use of discovery learning model with rme approach viewed from interpersonal intelligence," Journal of Education and Learning (EduLearn), vol. 13, no. 1, pp. 87-92, 2018.

[6] M. A. Khoiruddin \& D. D. Sholekah, "Islamic religion education implementation in forming student religious characters," Jurnal Pedagogik, vol. 6, no. 01, 2019.

[7] Astalini, D. A. Kurniawan, R. Perdana, and H. Pathoni, "Identification of student's attitude towards physics learning in 5 senior high school of Jambi (in bahasa)," Unnes Physics Education Journal, vol. 8, no. 1, 2019.

[8] F. Listrianti, "Urgency of character education in min 1 Probolinggo (in bahasa)," Jurnal Pedagogik, vol. 6, no. 1, 2019.

[9] Darmaji, D. A. Kurniawan, and A. Suryani, "Effectiveness of basic physics ii practicum guidelines based on science process skills," Jurnal Ilmu Pendidikan fisika, vol. 4, no. 1, pp. 1-7, 2017.

[10] R. Darmawangsa, Astalini, and D. A. Kurniawan, "Development of instrument of high school student's attitude towards physics subjects (in bahasa)," Jurnal Pendidikan Fisika Universitas Muhammadiyah Makassar, vol. 6, no. 1, pp.1-8, 2018.

[11] M. F. Hafa, H. Suwignyo, and A. Mudiono, "Application of inquiry model to improve activities and learning outcomes of science in class V students," Educational Journal: Theory, Research, and Development, vol. 2, no. 12, pp. 1644-1649, 2017

[12] A. Susilawati, H. Hernani, and P. Sinaga, "Implementation of project-based learning with mind mapping to increase student's environmental attitude towards waste management in junior high school," International Journal of Education, vol. 9, no. 2, pp. 120-125, 2017. 
[13] S. Sardinah \& T. Tursinawati, "The relevance of students' scientific attitudes to the concept of nature of science in conducting experiments on science learning at SDN Banda Aceh City," Journal of Science, vol. 13, no. 2, 2018.

[14] D.N. Anisa, M. Masykuri, and S. Yamtinah, "Impact of POE (predict, observe, and explanation) and Scientific Attitude towards Student's Achievement in Acids, Bases and Salts of grade VII fisrt semester of 1 Jaten Junior High School on 2012/2013 academic year (In Bahasa)," Jurnal Pendidikan Kimia (JPK), vol. 2, no. 2, pp. 16-23, 2013.

[15] R. Mukhopadhyay, "Scientific attitude-some psychometric considerations," IOSR Journal of Humanities and Social Science (IOSR-JHSS) OSR-JHSS, vol. 19, pp. 98-100, 2014.

[16] D. A. Kurniawan, Astalini, and L. Anggraini, "Evaluation of junior high school student's attitude on science major at Muaro Jambi Region (In Bahasa)," Jurnal ilmiah didaktika: Media Ilmiah Pendidikan dan Pengajaran, vol. 19, no. 1, pp. 124-139, 2019.

[17] S.C. Kuldeep, "Scientific attitude among senior secondary school students," International Journal of Applied Research, vol. 2, no. 5, 2016.

[18] G. B. Samudra, I. W. Suastra, and K. Suma, "Issuess faced by senior high school students at Singaraja city on learning physics (In Bahasa)," Jurnal Pendidikan IPA Indonesia, vol. 4, no. 1, 2014.

[19] Astalini, D. A. Kurniawan, R. Perdana, and D. Kurniasari, "Identification of student attitudes toward physics learning at Batanghari district high school," The Educational Review, vol. 2, no. 9, pp. 475- 476, USA, 2018.

[20] Astalini, D.A. Kurniawan, and A.D. Putri, "Identification of attitudes on social implications from science major, interest in increasing science learning time, and career interest in science major of junior high school students in Muaro Jambi Regency (in bahasa)," Jurnal Tarbiyah: Jurnal Ilmiah Kependidikan, vol. 7, no. 2, pp. 93-108, 2018.

[21] Astalini, D. A. Kurniawan, and Sumaryanti, "Student's attitude towards physics learning in batanghari district senior high school (in bahasa)," Jurnal Ilmu Pendidikan Fisika, vol. 3. pp. 59-64, 2018.

[22] Astalini, D. A. Kurniawan, R. Perdana, and W. Kurniawan, "Identification of student attitudes in physics subjects (in bahasa)," Jurnal Ilmu dan Teknologi Pendidikan, vol. 5, no. 1, pp. 39-48, 2019.

[23] Sugiyono, Mix Methods (in bahasa), Alfabeta, 2018.

[24] L. Cohen, L. Manion, and K. Morrison, Research Methods in Education (6th ed.), Routledge Falmer, 2007.

[25] Creswell, J. W, Educational Research: Planning, Implementing and Evaluating Qualitative and Quantitative Research (in bahasa), Pustaka Belajar, 2005.

[26] Sugiyono, Educational research methods (in bahasa), Alfabeta, 2018.

[27] E. P. Widoyoko, Research Instrument Designing Techniques (in bahasa), Pustaka Pelajar, 2016.

[28] S. Darius, A Handbook of statistic an overview of statistical methods, Bookboon the ebook company, 2017.

[29] Alison, Mackey. \& S. M. Gass, Second language research Methodology and Design, Lawrence Erlbaum Associates, Inc, 2005

[30] Dimyanti \& Mudjiono, Study and Learning (in bahasa), PT Rineka Cipta, 2009.

[31] A. Riwahyudin, "Student attitudes and student learning interests against student learning outcomes class v elementary schools in Lamandau district," Journal of Basic Education, vol. 6, no. 1. pp. 11-23, 2015.

[32] L. Fransiska and U. Rosidin, "Effect of student perceptions about scientists and scientific attitudes toward physics learning outcomes (in bahasa)," Jurnal Pembelajaran Fisika, vol. 1, no. 4, 2013.

[33] I. K. U. Astika, I. K. Suma \& I. W. Suastra, "The effect of problem-based learning models on scientific attitudes and critical thinking skills," Postgraduate E-Journal Program of Ganesha University of Education Science Study Program, vol. 3, no. 2, pp. 1-10, 2013.

[34] I. M. W. Astawa, I. W. Sadia, \& I. W. Suastra, "Effect of project-based learning models on scientific attitudes and self-concepts of junior high school students (in bahasa)," Jurnal Pendidikan dan Pembelajaran IPA Indonesia, vol. 5, no. $1,2015$.

[35] H. S. Putra, Asrial \& S. Hariyadi, "The influence of the media contextual approach (powerpoint) and scientific attitudes towards biology learning outcomes of SMAN 13 students in tebo regency (in bahasa)," Edu-Sains, vol. 3, no. 1,2015

[36] Syahrial, Asrial, D. A. Kurniawan, P. Nugroho, R. Septiasari, R. A. Pratama \& R. Perdana, "Increased behavior of students' attitudes to cultural values using the inquiry learning model assisted ethno constructivism," Journal of Educational Science and Technology, vol. 5, no. 2, pp.166-175, 2019.

[37] Astalini, D. A. Kurniawan \& L. Z. N. Farida, "Description of the attitudes of high school students in Batanghari based on indicators of researcher normality, adoption of scientific attitudes, interest in increasing time, and career interests in the field of physics (In Bahasa)," RKPF UAD, vol. 5, no. 2, 2018.

[38] D. A. Kurniawan, Astalini, Darmaji \& R. Melsayanti, "Students' attitude towards natural sciences," International Journal of Evaluation and Research in Education (IJERE), vol. 8, no. 3, 2019.

[39] Astalini, Darmaji, D. A. Kurniawan \& A. Destianti, "Description of the dimensions attitudes towards science in junior high school at Muaro Jambi," International Journal of Sciences: Basic and Applied Research (IJSBAR), vol. 47, no. 1, pp. 1-11, 2019.

[40] U. Narmadha \& S. Chamundeswari, "Attitudes towards science learning and academic achievement in science among students at intermediate level (in bahasa)," Jurnal Penelitian Sosiologis, vol. 4, no. 2, 2013.

[41] M. Musdar, "Mapping the physics concepts of class xi students in the 2013 curriculum (in bahasa)," Jurnal Pendidikan Fisika dan Keilmuwan (JPFK), vol. 4, no. 1, pp. 36-41, 2018.

[42] Afrizon, et all., "Increased character behavior and critical thinking skills of class ix students in the Padang Model in science-physics subjects using problem-based instruction models," Journal of Physics Learning Research, vol. 1, 2012.

Int. J. Eval. \& Res. Educ. Vol. 9, No. 1, March 2020: 54 - 61 
[43] F. P. Nursa'ada, "The effect of learning method and student attitude on science learning towards science learning outcomes (in bahasa)," Jurnal Formatif, pp. 112-123, 2014.

[44] R. Maharaj-sharma \& A. Sharma, "Using ICT in secondary school science teaching-what students and teachers in Trinidad and Tobago say?," vol. 3, no. 2, pp. 197-211, 2017.

[45] L. Halim, N. A. Rahman, R. Zamri \& L. Mohtar, "The roles of parents in cultivating children's interest towards science learning and careers," Kasetsart Journal of Social Sciences, 2017.

[46] A. Zalmansyah, K. Z. Nur \& M. Isnaini, "(The Influence of Language Regulation Knowledge to the Language Attitude of Culinary Entrepreneur at Kota Metro) (in bahasa)," Kandai, vol. 14, no. 2, pp. 149-168, 2018.

[47] Astalini, D. A. Kurniawan, Darmaji, L. Rofiatus, Sholihah \& R. Perdana, "Characteristics of students' attitude to physics in Muaro Jambi high school," Humanities \& Social Sciences Reviews, vol. 2, no. 7, pp. 96-97, 2019.

[48] D. E. Ukpong \& I. N. George, "Length of study-time behaviour and academic achievement of social studies education students in the university of uyo," International Education Studies, vol. 6, no. 3, pp. 172-178, 2013.

[49] Astalini, "Students' attitude towards physic learning at senior high school of Batanghari region (in bahasa)," Jurnal Ilmu Pendidikan Fisika, vol. 3, no. 2, pp. 59-64, 2018

[50] Asrial, Syahrial, D. A. Kurniawan, M. Subandiyo \& N. Amarlina, "Exploring obstacles in language learning among prospective primary school teacher," International Journal of Evaluation and Research in Education (IJERE), vol. 8, no. 2, pp. 249-254, 2019.

[51] Syahrial, Asrial, D. A. Kurniawan, F. Chan, A. Hariandi, R. A. Pratama, P. Nugroho \& R. Septiasari, "The impact of etnocontructivism in social affairs on pedagogic competencies," International Journal of Evaluation and Research in Education (IJERE), vol. 8, no. 3, pp. 409-416, 2019.

[52] Astalini, D. A. Kurniawan \& K. Hardiyanti, "Students' attitude towards physic lerning at 5 senior high school of muaro jambi (in bahasa)," Jurnal Pendidikan Fisika, vol. 3, no. 2, pp. 2-12, 2018.

[53] Darmaji, D. A. Kurniawan, A. Suryani \& A. Lestari, "An identification of physics pre-service teachers' science process skills through science process skills-based practicum guidebook," Jurnal Ilmiah Pendidikan Fisika AlBiRuNi, vol. 7, no. 2, pp. 239-245, 2018.

[54] Darmaji, D. A. Kurniawan, W. Kurniawan, K. Anwar \& A. Lumbantoruan, "Students' perceptions of electronic's module in physics practicum," Journal of Education and Learning (EduLearn), vol. 13, no. 2, pp. 288-294, 2019.

[55] Maison, Syahrial, Syamsurizal, and Tanti, "Learning environment, students' beliefs, and self-regulation in learning physics: Structural equation modeling," J. Balt. Sci. Educ., vol. 18, no. 3, pp. 389-403, Jun. 2019.

[56] Tanti, Maison, A. Mukminin, Syahrial, A. Habibi, and Syamsurizal, "Exploring the relationship between preservice science teachers 'beliefs and self-regulated strategies of studying physics : A structural equation model," J. Turkish Sci. Educ., vol. 15, no. 4, pp. 79-92, 2018. 